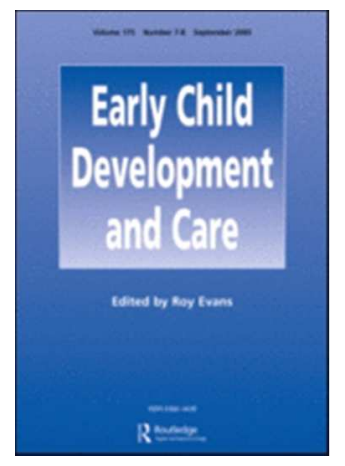

\title{
Early Years Teachers as leaders of change through reflexivity praxis?
}

\begin{tabular}{|r|l|}
\hline Journal: & Early Child Development and Care \\
\hline Manuscript ID & GECD-2018-0100 \\
\hline Manuscript Type: & Original Article \\
\hline Keywords: & $\begin{array}{l}\text { Early Years Teacher Status, leading change, impact, praxis, pedagogical } \\
\text { leaders }\end{array}$ \\
\hline \multicolumn{2}{|l}{} \\
\hline
\end{tabular}

\section{SCHOLARONE" \\ Manuscripts}




\title{
Early Years Teachers as leaders of change through reflexivity praxis?
}

\begin{abstract}
The contemporary 'notion' of Early Years Teacher Status (EYTS) is primarily associated with the professionalization and policy review of the Early Childhood Education and Care (ECEC) workforce in England. As such, although considered to advocate reputed prospects and potential for graduates 'leading' provision for under-fives, remains for many educationalists an ambiguous concern. This paper outlines the findings of a recent small-scale qualitative research study suggesting that EYTs, offered time and space to document and reflect on their provision, subsequently transform their own pedagogy and effectively lead their colleagues in making crucial changes to support early reading in their settings. The EYTs engaged in this study recognised a shortfall in their current provision and actively pursued resolution as reflexive pedagogical leaders.
\end{abstract}

Keywords: Early Years Teacher Status; leading change; impact; praxis; pedagogical leaders

\section{Introduction}

\section{Early Years Teacher Required}

Are you an inspirational, emotionally intelligent and resilient leader?

We require an Early Years Teacher who has high expectations and is an effective communicator, committed to supporting the outcomes of very young children. You will have a strong knowledge of child development and understand how young children learn best. You will be required to lead, manage and inspire a dedicated team to support the overarching vision of inclusive, innovative, high quality teaching and learning for under-fives.

This pseudo 'advertisement' is the result of a small group task in a University-based session, focusing on 'the role of the Early Years Teacher' with trainee Early Years Teachers (shared with their permission). This presents some clarity about how trainee Early Years Teachers envisage their role to be - or does it? It may also present a jumble 
of many educational 'buzzwords', undefined, potentially misunderstood, yet often associated with Early Years Teacher Status. High expectations indeed!

Early Years Teachers (EYTs) are demarcated by the National College of Teaching and Leadership (NCTL 2013, 1) as 'graduate leaders responsible for organising and leading high quality teaching practice in a range of early years settings'. EYTs are expected to critically reflect, as pedagogical leaders on all aspects of early years provision (NCTL 2014). The concept of Early Years Teacher Status, as 'graduate leaders' arose from hybrids of the Nutbrown Review (2012), the More Great Childcare Report (DfE, 2013) and the previous iterations of Early Years Professional Status (EYPS, CWDC 2006) to nurture the status and impact on the 'quality' of the Early Childhood and Care (ECEC) workforce. Formerly, The Children's Workforce Strategy (DfES 2006) advocated that quality provision stipulates an investment in a suitably well-qualified workforce. Conversely, McDowall Clark and Bayliss (2012) and Campbell-Barr (2018) both propose that the requirement of graduates leading provision is a relatively new position for the UK, compared to international expectations of ECEC professionals. However, given that the professionalization of the ECEC workforce is susceptible to a breadth of policy and educational reviews in the UK, relating to the promotion of graduates being 'leaders' of practice (Coates and Faulkner 2013; CWDC 2007; DfE 2014; Gaunt 2013; Lloyd and Hallett 2010; Moss 2014; NCTL 2013; Parker, 2013), it is not surprising that EYTS sustains some antagonism. Particularly, as graduates working across the ECEC workforce are still facing the sensitivity of the low status of working with very young children (Elfer and Page 2015; Goouch and Powell 2013; Manning-Morton 2006), the contradiction of care and professionalism viewpoint proposed by Moss (2014) and are often largely working within the insufficiently supported non-maintained sector, therefore poorly paid (Adamson and Brennan 2014). 
Furthermore, Horwood et al. (2013) propose that there are also many international sensitivities surrounding the diverse perceptions of professionalization prevailing for ECEC.

In addition, the equivocal concept of 'quality' emerges as a recurrent subjective premise (Penn 2011; Moss 2014; Murray 2018). Previous research suggests that the quality of the ECEC settings is directly aligned with the 'quality' and status of the staffing (Sylva et al, 2004; OECD 2012; Mathers et al. 2007). Indeed, Mathers and Smees (2014) in their Nuffield Report 'Quality and Inequality; Do three-and-four-yearolds in deprived areas experience lower quality early years provision?' disclose that graduate EYTs influence the overall quality of the provision for three and four year olds. Equally, Rodd (2006) suggests that earlier studies also highlight effective leadership (graduates) as the principle characteristic of influencing the quality of ECEC settings. In contrast, Mathers et al. (2011) in their report on the Graduate Leader Fund, state that there is insufficient verification that graduate Early Years Professionals (EYPs) actually have an impact on the overall quality of provision for very young children Yet, Hadfield et al. $(2012,7)$ note that EYPs, as leaders of pedagogy 'improved the quality of practice in general'. This ambiguity surrounding the notion of graduates influencing the quality of provision is conceivable, given that Moss $(2010,30)$ contends that 'the concept of quality is not neutral' and is also 'socially constructed'. Quality, for many international researchers and educationalists is still left clearly undefined. Indeed, Penn (2011) advocates that:

Quality is nothing if not relative, and there are no magic formulae, only many adjustments to suit each set of circumstances.

(Penn, 2011, 6)

Consequently, the misleading discourse of quality from policy makers is usually associated with 'measured' assessment and achievement outcomes (Roberts-Holmes 
2015), which has wider global implications for quality and subsequently leadership resolutions (Moss 2017).

\section{Insecurities of the 'status' of leadership}

Nupponen (2006) advocates that successful leadership is pivotal to the discourse surrounding quality. However, Osgood (2004, 2012) and Muijs et al. (2004) contend that leadership also contains its fair share of nebulousness. Waniganayake $(2002,18)$ maintains that 'anyone in early childhood can be a leader' regardless of status. Intrinsically, Nutbrown (2012) suggests in her Foundations for Quality. The independent review of early education and childcare qualifications that:

All early years practitioners should aspire to be leaders, of practice if not of settings, and all should be capable of demonstrating some pedagogical leadership regardless of qualification level.

(Nutbrown, 2012, 55)

This is somewhat problematic, given that Cottle $(2011,261)$ proposes the overall perception of quality and leadership for many 'can be elusive and dynamic'. The potential for such dynamic complications arises from EYTs as leaders 'whose roles have been defined by external agendas and prescriptive standards' (Hammond, Powell and Smith 2015, 144). As such, Murray and McDowall Clark $(2013,290)$ highlight that pedagogical leadership 'is not uniformly understood in England or internationally', although deemed an essential concept for the ECEC workforce (Carroll-Meehan, Bolshaw and Hadfield 2017). Certainly, the same can be said of leadership in general. Leadership is a thorny, problematical concept within the confines of ECEC. EYTs as pedagogical leaders could be defined as 'influencers' who support colleagues in achieving mutual aspirations (Northouse and Lee 2016). However, as Beattie (2017) highlights, leadership is never devoid of the power dimension as a global construct, 
given that policy makers have already decided the agenda and the 'agency' of EYTs. The agency being the conduit between the EYT's chosen leadership focus and the colleagues as learners. Børhaug (2013) believes that this then contests the constructs of pedagogical leaders, as there is almost certainly a hierarchical dimension to their role. Therefore, Bøe and Hognestad (2017) suggest that a model of distributed pedagogical leadership is necessary and is more collaborative in nature. Murray $(2013,528)$ proposes that EYPS and potentially EYTS (as the contemporary iteration of EYPS) are leaders 'without a defined hierarchical position', expected to accomplish transformation as representations of pedagogical quality. The many alternative complexities of leadership in ECEC are also concerned with the tension between organisational and pedagogical leadership (Avery 2004; Rodd 2006; Siraj-Blatchford and Manni 2007; Whalley 2008). For example, Mistry and Sood (2012) maintain that leaders working in early years settings often switch between their roles as leaders and managers to work effectively for all stakeholders.

\section{EYTS as a model for reflective, transformational leadership}

Reflective leadership is often focused on change and enrichment, alongside encouragement and challenge to reconceptualise (Robertson, 2005). Arguably, thus related to both the underpinning depth of knowledge and the successful implementation of any transformations of pedagogy. EYTS is designed primarily as a training model, prescriptive in the assessment of the Teachers' Standards (Early Years, NCTL 2013), yet also involves and encourages aspects of reflective leadership, based on the impact the individual EYT has on the setting, as the transformational leader (Osgood 2010). This suggests a position of non-hierarchical leadership and was certainly the intention of EYPS (Mathers et al. 2011). Many researchers believe that the ECEC workforce is 
already reflective and transformative, regardless of status, given the passionate, participatory nature and vision of individuals dedicated to their profession (Oberhuemer 2005, 2018). Furthermore, Murray and McDowall Clark (2013, 290) propose an ideal scenario of reframing aspects of leadership to include reflection as professional practice so that 'pedagogy can be formulated as a leadership concept integral to professionalism'. Equally, Rodd (2006) and Carroll-Meehan, Bolshaw and Hadfield (2017) advocate that leadership, as a concept in early years ought to be related to a collaborative team approach, focusing primarily on motivation, guidance and support for all.

Transformational leaders are expected to affect change within individuals and across social contexts; therefore inspiring colleagues to become leaders themselves. The potential of EYTs as transformational leaders is still relatively un-researched.

Furthermore, this often becomes obscured in the alternative complexities relating to the debates of professionalism, diversity of roles, dichotomies of care and education and perceptions of status. Indeed, these are all equally important facets of the preamble relating to EYTS and remain as fundamental anxieties. However, this paper is focused on the impact of change, when EYTs engage in reflective pedagogical practice 'leadership that is context dependent rather than 'model' dependent' (Male Palaiologou $2013,215)$

This paper presents the findings of a small-scale mixed methods empirical study, exploring EYTs reflexive pedagogical leadership. The EYTs in this study document and reflect on their own practice and that of colleagues in their settings and consequently formulate important changes to provision, based on engagement with and the personal agency of reflection. 


\section{The study}

This study comprises of an initial scoping survey questionnaire, followed by reflective Zine accounts to explore the perceptions and challenges of EYTs in supporting early reading for under-fives. Desyllas and Sinclair (2013) describe the Zine as a booklet utilised to collect a wealth of introspective data, which can be presented in any chosen format. As such, Radway (2011) suggests Zines could be considered to be original, as a novel approach - the 'ownership' of the amount of information and how to share the information is solely determined by the participants, not the researcher. The research questions sustaining the methodology are:

- What are the experiences and challenges of Early Years Teachers in supporting under-fives with early reading?

- How do these experiences impact on provision for early reading in settings?

The survey questionnaire, containing a mixture of open 'writing frame' opportunities and some closed questions was distributed to 70 potential participants and remarkably, $52 / 70$ completed surveys were returned. Given that the intention of the study was to seek the views and opinions of EYTs, alongside their pedagogy, a mixed methods interpretative methodology, advocated as a strength by Johnson and Onwuegbuzie (2004) and Walliman (2016) was employed overall. The survey questionnaire was complemented by 3 detailed reflective Zines, as a pragmatic approach to gathering effective operational data.

The intention was to explore the experiences of the EYTs in supporting early reading and to enable the EYTs to utilise the Zines as reflections for their continued professional development (CPD) and become an important part of their daily practice. Therefore it is critical that the EYTs' Zine entries have complete ownership and are personal to each EYT and their settings. Appleby and Andrews $(2011,57)$ assert that this approach of on-going reflection is a 'complex, multi-faceted process which in its 
most effective form is personalised and owned by practitioners'. Each volunteer was provided with a blank Zine booklet (Figure 1) to respond to the research question. No other guidelines or instructions, other than ethical aspects were provided for the EYTs. As such, each Zine presents as unique to the EYT and unlike any other (Figure 2). The EYTs completed the Zines from November 2015 to July 2016. Subsequently, all 3 EYTs requested to continue with their Zines until March 2017.

\section{Figure 1}

\section{Figure 2}

The survey data was originally recorded using Microsoft Excel Spreadsheets to create visual tables and graphs. Themes were then explored using Schreier's Qualitative Content Analysis (QCA) (Schreier, 2012) to manually code and were subsequently combined with NVivo Pro 11 (QSR International) to investigate the emergent codes and themes further. The main findings have been reported previously as part of a wider Doctoral Thesis (Author 2017). This paper highlights one of the incipient themes of 'changing pedagogy', based on engagement with the study.

\section{Participants}

The majority $(94 \%, 49)$ of the EYTs who volunteered to take part were female; $6 \%$ (3) are male, which is relatively aligned with the wider ECEC workforce statistical data (DfE 2013 National ECEC Workforce Census, DfE 2016 School Workforce in England). However, no male EYTs participated in completion of the Zines after the initial survey questionnaire. Whilst gender equality remains a concern for the ECEC workforce, the fact that no male EYTs completed a Zine did not detrimentally impact on the purpose of this study. The EYTs are within the $21-45$ years age range and have a 
breadth of experience in early years settings, from 3 years 24 years. All EYTs are graduates with an Honours Degree in an Early Childhood Education related subject and the majority of the EYTs are employed in a leadership role in their settings in England. Figure 3 presents an overview of the volunteer Zine participants:

\section{Figure 3}

Ethical principles are adopted consistently throughout this research study, adhering to the British Educational Research Association (BERA 2011) Ethical Guidelines for Educational Research and European Early Childhood Education Research Association Ethical Code for Early Childhood Researchers (EECERA 2014). The EYTs were instructed to respect and maintain confidentiality whilst completing the Zine entries (no names or photographs of children or staff) and also advised to share the research aims and objectives provided to them with parents, carers, colleagues, managers and governors, as appropriate.

\section{Findings and discussion}

The EYTs in this study recurrently contemplated their practice and that of their colleagues, consequently revising or enhancing the provision in their settings based on engagement and review of the reflective Zine entries. May and Perry $(2014,120)$ describe this process of reflection and subsequent action as a 'transformative outcome', where the EYTs effectively become 'decision-makers to consider the challenges and to rethink current practice and preconceptions'. Early on in the study, the sense of reflexivity and frustration is apparent in this Zine entry:

I realised that when I am completing this Zine that I keep writing things like I put the basket of books on the carpet for our toddlers, I got the story props out today. What am I doing - these need to be out 
all the time? Why am I deciding when this happens? I'm really disappointed in myself, but at least I have had the opportunity to sort it out now!!!!

(Zine 2)

Whilst completing this Zine routinely, the EYP has noticed that her provision for early reading is lacking in 'access' for the children and without prompting or apparent influence appreciates the opportunity to resolve. Indeed, Siraj-Blatchford and Manni $(2006,28)$ propose that engagement in reflective activities 'often acts as an impetus for change' and this then becomes further 'motivation for on-going learning and development', which is evident in this study. This later Zine entry highlights that this particular EYT is addressing the previous concerns about the provision:

Today, we have books, picture books particularly in our baby and toddler rooms - we have made a space for the basket of books on the carpet area so that it is constantly out and agreed on sharing books between rooms.

\section{(Zine 2)}

Accordingly, it appears that leading this review of provision and access is not going to be an easy 'change' to make, as this later entry illustrates:

I have just had to get the basket of books from the shelf! Apparently, they were in the way on the carpet and the babies were not doing anything with them. I think I have some staff training to deliver!!!

(Zine 2)

The EYTs' proficiency to enhance their own provision for early reading, through reflection and depiction, as opposed to the instruction based training often recommended for continued professional development (CPD), such as Early Years Teacher Status (NCTL, 2015) is distinctive within this study. Early Years Teacher Status (EYTS) is achieved based on the recommendation of meeting and evidencing 8 prescriptive Teachers' Standards (Early Years, NCTL 2015) in practice. Consequently, the Zine entry does refer to the team requiring some 'staff training'. It appears that the 
practitioners working in this setting are unsure about how best to engage babies with books and may not be aware that independent access is a significant feature of early reading (Boardman 2017). There are no similar entries, so it is presumed that the staff training supported these practitioners with this particular aspect. Therefore the EYT has demonstrated acute awareness of the complexity of her role as a successful, emotionally intelligent leader in suggesting this is a much bigger issue, requiring staff development and perhaps some 'bigger picture thinking' for the team. This also indicates that there is potentially some negativity or challenges to overcome in reaching a successful outcome for the babies in this setting. Centrally, there is underlying evidence of transformational leadership across these Zine entries, with the possibility of the EYT energising, motivating and inspiring change. However, opposing viewpoints could also cogitate that this may have been achieved in alternate ways, utilising power or authority over what Fenech and Sumison $(2007,119)$ describe as 'othering' of the lesser qualified colleagues in the setting, who are not designated as EYTs.

Moreover, there is consistent evidence from the data of EYTs leading 'change' in their settings, based on these reflective accounts. Osgood (2012) maintains that the opportunity for professional development, involving reflective practice, rather than any prescriptive mandatory training sustains the greatest impact. Consequently, the EYTs become critically reflective of their own pedagogy and demonstrate the aptitude to critique and enrich their own practice with some thoughtful and occasionally challenging reflections, leading to change. The following Zine entries illustrate this:

I'm working in the pre-school room today to support the staff team. We have identified that the book area is not being used well.

The next Zine entry states:

I can say that the book area is not used at all!! I will put this on the agenda for the next room leaders meeting.

(Zine 3) 


\section{Revision Point}

I feel like we might need to complete an audit of where our bookcases are and if we can make this better for all to access. We've noticed that it is the same children that bring you a book for a story or to look at. Why aren't the others doing this?

Are they not interested?

Do we have the right sort of books?

Is it girls more than boys?

How else are the others reading then?

How do we address and monitor this? Is it important or are children making independent choices?

(Zine 1)

This Zine 1 entry is particularly thoughtful with clear intention and agency, described by Bandura $(2001,23)$ as 'personal agency being achieved through reflective and regulative thought'. The list of questions posed demonstrates some self-efficacy, which may influence the motivation to resolve the issue of access raised in earlier Zine entries for this setting. Furthermore, these Zine entries illustrate that by focusing on one area of provision - 'early reading', in response to the research questions, the scope for reflection is being channelled and prioritised, leading to a specific 'lens' being applied for the reflections. The initial survey responses all noted that the knowledge gained from 'previous training programmes', 'CPD', 'Local Authority (LA) training', 'Alliance Partner training', 'staff development sessions' and 'knowledge of child development' contributes to the chosen rationale to support early reading provision. None of the survey responses mentioned 'reflection' as an initiative to influence provision or pedagogy, although 'observation of practice' did feature in some survey responses. The findings highlight that reflection is the key agent of change for early reading provision in this study. As such, the Zines have provided a mechanism and the opportunity to observe, note, reflect and 'act' as a praxis. Freire $(1986,36)$ describes a praxis as 
'reflection and action upon the world in order to transform it'. On this occasion, the

provision for early reading as a prominent focus leads to significant changes for under-

fives, evident in these Zine entries:

I have totally enhanced the toddler environment - accessible books, story sacks available and accessible. I read books daily with our toddlers now and I monitor this - we carefully choose books to offer more language. Early reading is a key focus now for us. I think about how we, as adults model reading all the time.

(Zine 3)

Staff Development Session (Jan 2017)

We covered supporting early reading - rhythm, rhyme, steady beat etc. We reviewed how we approach nursery rhymes - do the children understand the rhymes? Using lots of props now so that children can match the object to the rhyme and choose. The children love this activity. This has had the biggest impact for our setting.

(Zine 1)

I have chosen to lead on early reading and also to support phonics for my setting. We still have a lot of work to do - but everyone is on board!

(Zine 2)

All the EYTs completing the Zines recorded aspects of pedagogical leadership, in that there has obviously been some crucial engagement and 'change conversations' to improve provision, leading to leadership for learning suggested by Nuttall, Thomas and Henderson (2016). Here the pedagogical leadership is what Bøe and Hognestad (2017, 145) refer to as more of a 'hybrid leadership'- that is 'leaders that understand the practice of leading staff'. The reciprocal comment 'but everyone is on board' is an example here. These Zine entries also suggest that the EYTs are leading by modelling practice, perhaps developing greater insight into their own and others' practice.

\section{Final Zine Entries}


Before final submission of their Zines, the EYTs were asked to complete a final Zine entry, relating to the perceived impact overall of engaging in the research study or anything further they wished to include. The final entries included a summary of the overall benefits of completing the Zines:

Being able to make changes and improve things on-going has been of greatest benefit. This has enhanced my role as an EYT in the setting. I am now leading on literacy and early reading, supporting others, including parents. It is nice when the staff team come to me for advice and even better when they take my advice. I still have loads to learn, but the starting point is not so far behind now.

\section{(Zine 3)}

Here, this experienced EYT has recognised that the central benefit has been to make the necessary changes to provision as an on-going process, with the engagement of her team. This is a further example of Bøe and Hognestad's (2017) 'hybrid leadership' approach. This final note alludes to some repositioning, challenging and extending thought taking place. There is also a sense of self-efficacy shaped by some self-belief in the perceived successful achievements, as the designated 'go to person' for advice, integrated into the role as leader within the narrative of 'I am now leading on'.

The chance to reflect, observe, note and reflect again on an on-going basis has been really important for us. I feel that I have better working relationships with the team now and my opinion feels important. I have also developed my knowledge and understanding of early reading. I probably have more questions than answers, but it's a good start.

(Zine 1)

This Zine entry cites 'better working relationships', which is often an essential component of pedagogical leadership (Burman 2001). The use of 'us' offers a consensus of collaboration and indicates promising transformational leadership attributes. Reflection has obviously been pivotal for this collaborative practice, 
requiring what Oberhuemer $(2018,1)$ refers to as some 'unravelling and disentangling' as part of the reflection overview process. Zine 2 refers to the usefulness of 'standing back, reviewing and enhancing':

It has been really useful in standing back, reviewing and enhancing practice, resources, access and supporting the team. We have made a good start - lots to focus on and develop further. We have found this useful so will continue to reflect in this way!

(Zine 2)

It is interesting to note that each of these final Zine entries highlights that reflection is the beginning of the process for their settings - a continuum of learning. This demonstrates that this on-going reflective process has led to some useful pedagogical enrichment, whilst focusing on one particular area of early reading.

\section{Final Thoughts}

The EYPs in this small-scale study engage in reflexive narratives that effectively lead to a critical understanding of their role as an EYT in leading on an aspect of provision requiring enhancement; early reading in this circumstance. The EYTs recognise some discrepancies for their settings whilst engaging in the study, such as access to resources, deployment of resources, knowledge, perception and understanding of their colleagues. Consequently, the EYTs strive to enrich these areas to raise the quality of provision for early reading.

Essentially, the EYTs taking part in this study consider these reflections as the beginning, implying future action, potential for more collective transformational changes. This research study has enabled the EYTs to engage in experiential leadership pedagogy to understand and support their teams to make necessary changes to practice. This study also highlights the complexity of the role of an EYT and demonstrates the 
amassed demands, understanding and potential qualities required of ECEC educators as ‘leaders' of quality (Campbell-Barr 2018).

Returning to the pseudo EYT post - it is perhaps unachievable for anyone working in the ECEC workforce or in a leadership role. Nevertheless, it is feasible that many ECEC professionals, regardless of their status, pay or working conditions strive to meet these high expectations on a daily basis and actually do so (Murray 2018). These small-scale research study findings suggest that the EYTs are improving the overall quality of provision for under-fives in their settings, specific to early reading and acting as 'thoughtful agents' (Appleby and Andrews 2011, 59). The Zines, as a methodology have enabled situational, socially constructed interpretative data to empower these EYTs to engage in reciprocal and participative transformational pedagogy. Regardless of the ambiguity of EYTS training or it's 'status', this paper suggests that EYTs are thoughtful pedagogical leaders that undoubtedly impact on the quality of provision when engaged in reflexive praxis. However, it is acknowledged that more evidence is required to maintain this stance.

\section{Figure 1}

Figure 2

\section{Figure 3}




\section{References}

Adamson, E. and Brennan, D. 2014. 'Social investment or private profit? Diverging notions of 'investment' in early childhood education and care'. International Journal of Early Childhood. 46 (1). 47-61.

Appleby, K. and Andrews, M. 2011. 'Reflective practice is the key to quality improvement'. Reed, M. and Canning, N. Eds. Quality improvement and change in the early years. London: Sage Publications.

Avery, G. 2004. Understanding Leadership. London: Sage Publications.

Bandura, A. (2001) 'Social cognitive theory: and agentic perspective'. Annual Review of Psychology. 52. 1-26.

Beattie, L. 2017. 'Educational leadership: a nirvana or a battlefield? A glance into the higher education in the UK using Bourdieu'. International Journal of Leadership in Education. DOI: 10.1080/13603124.2017.1330490.

BERA. 2011. Ethical Guidelines for Educational Research. UK: British Educational Research Association

Bertram, T. Formosinho, J. Gray, C. Pascal, C. and Whalley, M. 2016. 'EECERA ethical code for early childhood researchers'. European Early Childhood Education Research Journal. 24 (1) iii-xiii.

Bøe, M. and Hognestad, K. 2017. 'Directing and facilitating distributed pedagogical leadership: best practices in early childhood education'. International Journal of Leadership in Education. 20 (2). 133-148.

Børhaug, K. 2013. 'Democratic early childhood education and care management? The Norwegian case'. Hujala, H. Waniganayake, M. Rodd, J. Eds. Researching leadership in early childhood education. 145-162. Tampere: Tampere University Press, Tampere.

Burman, E. 2001. Beyond the baby and the bath water: Post-dualistic psychologies for diverse childhoods. European Early Childhood Education Research Journal. 9. 5-22.

Campbell-Barr, V. 2018. 'The silencing of the knowledge-base in early childhood education and care professionalism'. International Journal of Early Years Education. 26 (1).75-89. DOI: 10.1080/09669760.2017.1414689.

Carroll-Meehan, C. Bolshaw, P. and Hadfield, E. 2017. 'New leaders in Early Years: making a difference for children in England'. Early Child Development and Care. DOI: 10.1080/03004430.2017.1324436.

Children's Workforce Development Council (CWDC). 2006. The Early Years Professional Prospectus. London: CWDC. 
Coates, E.A. and Faulkner, D. 2013. 'International Perspectives on Progress, Change and Development in Early Childhood Education and Care, 1993 to 2013'. International Journal of Early Years Education. 21 (2 -3) 244 - 263.

Cottle, M. 2011. 'Understanding and achieving quality in Sure Start Children's Centres: practitioners' perspectives'. International Journal of Early Years Education. 19 (3 - 4). $249-265$.

Department for Education. 2016. School Workforce in England. London: Department for Education (DfE).

Department for Education. 2013. National ECEC Workforce Census. London: Department for Education (DfE).

Department for Education. 2013. More Great Childcare. Raising Quality and giving parents more choice. London: Department for Education (DfE).

Department for Education and Skills (DfES). 2006. Children's Workforce Strategy: The Government's Response to the Consultation. London: DfES.

Desyllas, M. C. and Sinclair. A. 2013. 'Zine-Making as a Pedagogical Tool for Transformative Learning in Social Work Education'. Social Work Education: The International Journal. Volume 33 (3) 296-316.

EECERA Ethical Code for Early Childhood Researchers. 2014. EECERA.

Elfer, P. and Page, J. 2015. 'Pedagogy with babies: perspectives of eight nursery managers'. Early Child Development and Care. 185 (11-12) 1762 -1782.

Fenech, M. and Sumsion, J. 2007. 'Early Childhood Teachers and Regulation: Complicating power relations using a Foucauldian lens'. Contemporary Issues in Early Childhood. 8 (2). 109-122.

Freire, P. 1986. Pedagogy of the Oppressed. New York: Continuum Press.

Gaunt, C. 2013. 'Early Years Standards Ignore Sector Views'. Nursery World.

Goouch K. and Powell S. 2013. 'Orchestrating professional development for baby room practitioners: Raising the stakes in new dialogic encounters'. Journal of Early Childhood Research. 11 (1). 78-92.

Hadfield, M. Jopling, M. Needham, M. Waller, T. Coleyshaw, L. Emira, M. and K. Royle. 2012. Longitudinal study of Early Years Professional Status: An exploration of progress, leadership and impact. Final Report. University of Wolverhampton:

CeDARE.

Hammond, S. Powell, S. and Smith, K. 2015. 'Towards mentoring as feminist praxis in early childhood education and care in England'. Early Years. 35 (2). 139-153. DOI: 10.1080/09575146.2015.1025370. 
Harwood, D. Klopper, A. Osanyin, A. and Vanderlee, M. 2013. 'It's more than care: early childhood educators' concepts of professionalism'. Early Years. 33(1). 4-17.

Johnson, R. B. and Onwuegbuzie, A. J. 2004. 'Mixed Methods Research: A Research Paradigm Whose Time Has Come'. Educational Researcher. 33 (7). 14-26.

Lloyd, E. and Hallet, E. 2010. 'Professionalising the Early Childhood Workforce in England: work in progress or missed opportunity?' Contemporary Issues in Early Education. 11 (1) 75-88.

Male, T. and Palaiologou, I. 2015. 'Pedagogical leadership in the 21 st century: Evidence from the field'. Educational Management Administration \& Leadership. 43 (2). 214-231.

Manning-Morton, J. 2006. 'The personal is professional: Professionalism and the birth to three practitioner'. Contemporary Issues in Early Childhood. 7 (1) 42-52.

Mathers, S. H. Ranns, A. Karemaker, A. Moody, K. Sylva, J. Graham, and I. SirajBlatchford. 2011. Evaluation of the Graduate Leader Fund. Final Report. London: Department for Education. Available from https://www.education.gov.uk/publications/standard/publicationDetail/Page1/DFERR144.

Mathers, S. Sylva, K. and Joshi, H. 2007. 'Quality of Childcare Settings in the Millennium Cohort Study'. DfES Research Report. SSU/2007/FR/025. https://www.education.gov.uk/publications/eOrderingDownload/SSU2007FR025.pdf

Mathers, S. and Smees, R. 2014. Quality and Inequality. Do three- and four-year-olds in deprived areas experience lower quality early years provision? London: The Nuffield Foundation.

May, T. and Perry, B. 2014. 'Reflexivity and the Practice of Qualitative Research' in Flick, U. Ed. The SAGE Handbook of Qualitative Data Analysis. London: SAGE Publications. 109-123.

McDowall Clark, R. and Baylis, S. 2012. 'Wasted down there': policy and practice with the under-threes. Early Years. 32 (2). 229-242.

Mistry, M. and Sood, K. 2012. 'Challenges of Early Years leadership preparation: a comparison between early and experienced Early Years practitioners in England'. Management in Education. 26 (1). 28-37.

Moss, P. 2017. "Power and resistance in early childhood education: From dominant discourse to democratic experimentalism". Journal of Pedagogy. 8 (1): 11-32.

Moss, P. 2014. Transformative Change and Real Utopias in Early Childhood Education: A story of democracy, experimentation and potentiality. Oxon: Routledge.

Moss, P. 2010. 'We Cannot Continue as We Are; the Educator in and Education for Survival'. Contemporary Issues in Early Childhood. 11 (1). 8 - 19. 
Muijs, D. Aubrey, C. Harris, A. and Briggs, M. 2004. 'How do they manage? A review of the research on leadership in early childhood'. Journal of Early Childhood Research. 2 (2) $157-160$.

Murray, J. 2013. 'Becoming an early years professional: developing a new professional identity'. European Early Childhood Education Research Journal. 21 (4). 527-540.

Murray, J. and McDowall Clark, R. 2013. 'Reframing leadership as a participative pedagogy: the working theories of early years professionals'. Early Years. 33 (3). 289-301.

National College for Teaching and Leadership. 2013. Teachers' Standards (Early Years). London: NCTL.

National College for Teaching and Leadership. 2014. Early years initial teacher training requirements and supporting advice. 2014 - 2015. London: NCTL.

Northouse, P. G. and Lee, M. 2016. Leadership case studies in education. London: Sage.

Nutbrown, C. 2012. Foundations for Quality. The independent review of early education and childcare qualifications. Final Report. Department for Education.

Nuttall, J. Thomas, L. Henderson, L. 2016. 'Formative interventions in leadership development in early childhood education: The potential of double stimulation' Journal of Early Childhood Research. 1- 12.

Nupponen, H. 2006. 'Leadership concepts and theories; Reflections for practice for early childhood directors'. Australian Journal of Early Childhood. 31 (1) 43 - 50.

OECD. 2012. Starting Strong III - A Quality Toolbox for Early Childhood Education and Care. Paris: The Organisation for Economic Co-operation and Development. OECD.

Oberhuemer, P. 2018. 'Interlinking personal, professional and political perspectives in early childhood research'. European Early Childhood Education Research Journal. 26 (1). 1-6. DOI: 10.1080/1350293X.2018.1413782.

Oberhuemer, P. 2005. 'Conceptualising the Early Childhood Pedagogue: Policy Approaches and Issues of Professionalism'. European Early Childhood Education Research Journal. 13 (1) 5 - 16.

Osgood, J. 2012. Narratives from the Nursery: Negotiating professional identities in early childhood. Abingdon, Routledge.

Osgood, J. 2010. 'Reconstructing Professionalism in ECEC'. Early Years. 30 (2). 119 133. 
Osgood, J. 2004. 'Time to get down to business? The Responses of Early Years Practitioners to Entrepreneurial Approaches to Professionalism'. Journal of Early Childhood Research. 2 (1) $5-24$.

Parker, I. 2013. Early Developments: Bridging the Gap between Evidence and Policy in Early Years Education. London: IPPR.

Penn, H. 2011. Quality in Early Education and Care: An International Perspective. Maidenhead: Open University Press/McGraw Hill.

Radway, J. 2011. 'Zines, Half-Lives, and Afterlives: On the Temporalities of Social and Political Change'. PMLA. 126 (1) 140-150.

Robertson, J. 2005. Coaching leadership. Building educational leadership capacity through coaching partnerships. Wellington: NZCER Press.

Roberts-Holmes, G. 2015. 'The 'datafication' of early years pedagogy: 'if the teaching is good, the data should be good and if there's bad teaching, there is bad data'. Journal of Education Policy. 30 (3) 302-315.

Rodd, J. 2006. Leadership in Early Childhood. 3rd Edition. Maidenhead: Open University Press.

Schreier, M. 2012. Qualitative Content Analysis in Practice. London: Sage Publications.

Siraj-Blatchford, I. and L. Manni. 2007. Effective Leadership in the Early Years Sector: the ELEYS Study. London: Institute of Education, University of London.

Sylva. K. Melhuish, E. Sammons, P. Siraj-Blatchford, I. Taggart, B. and Elliot, K. 2004. The effective provision of pre-school education (EPPE) project: Findings from the preschool period summary findings. London: Department for Education and Skills.

Walliman, N. 2016. Social Research Methods. London: Sage Publications.

Waniganayake, M. 2002. 'Growth of Leadership: with Training, Can Anyone Become a Leader?' In Leadership in Early Childhood Education: Cross-Cultural Perspectives. V. Navala, V. and Hujala, E. eds. Oulu, Finland: Oulu University Press.

Whalley, M. 2008. Leading Practice in Early Years Settings. Exeter: Learning Matters Ltd. 
Figure 1 (blank Zine)

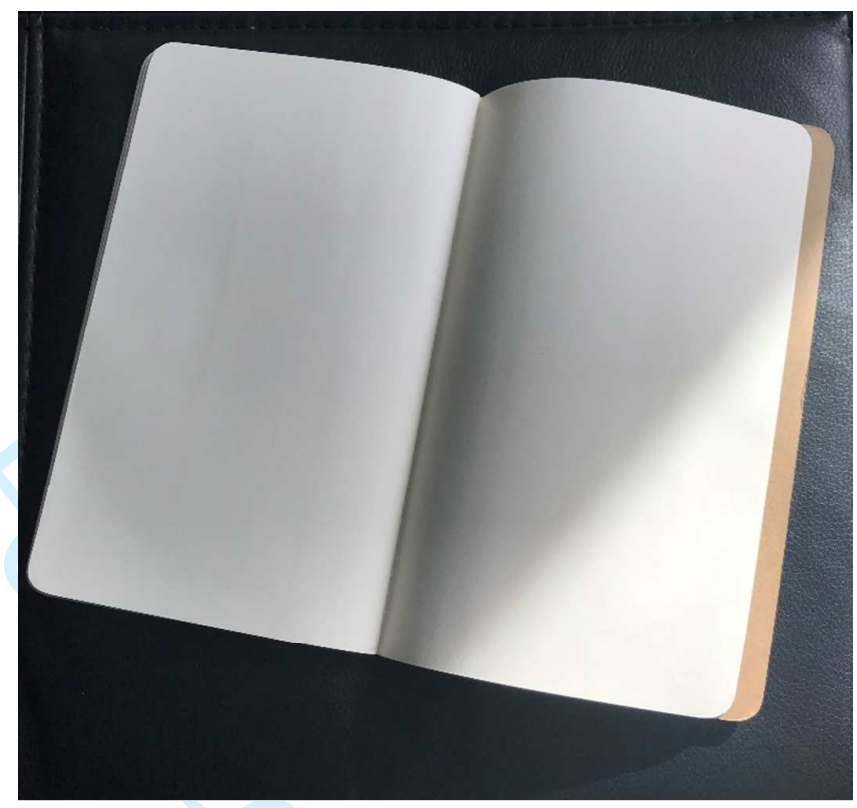

Figure 2 (sample Zines)

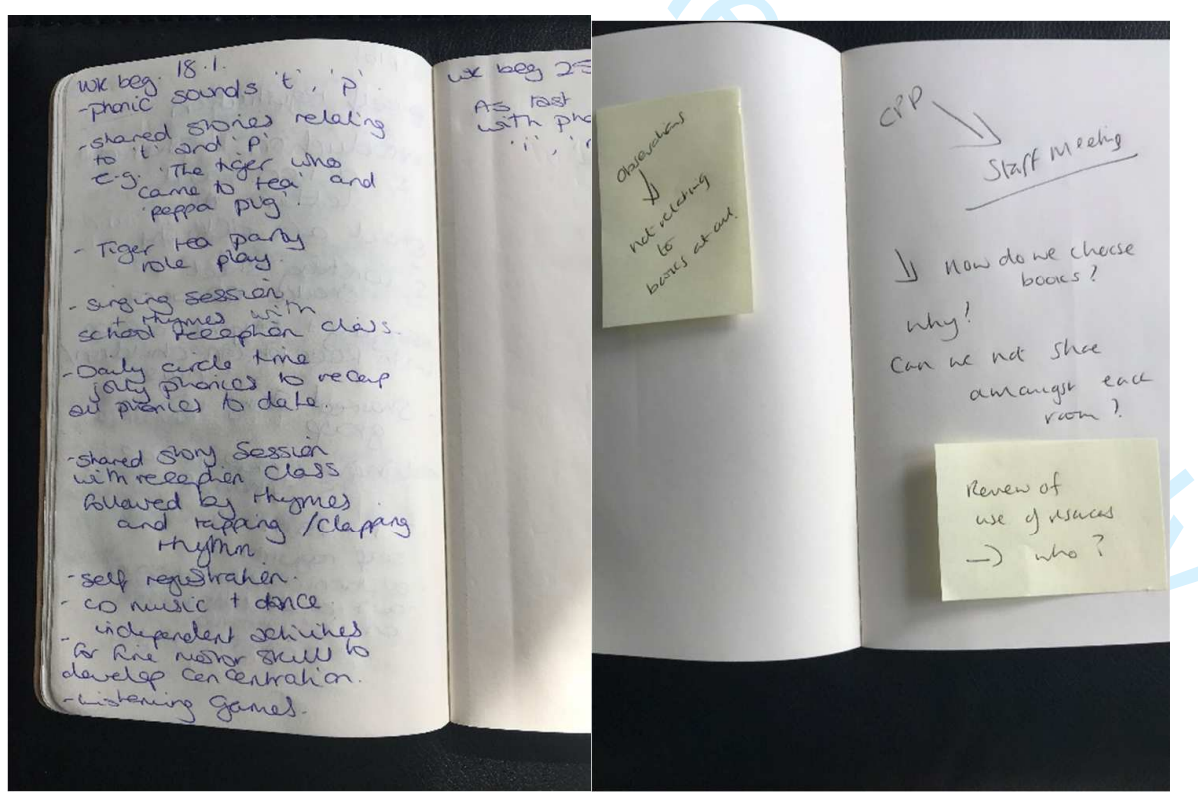


1

2

3

4

5

6

7

8

9

10

11

12

13

14

15

16

17

18

19

20

21

22

23

24

25

26

27

28

29

30

31

32

33

34

35

36

37

38

39

40

41

42

43

44

45

46

47

48

49

50

51

52

53

54

55

56

57

58

59

60

Figure 3 (Zine participants)

\begin{tabular}{|c|c|c|c|}
\hline Zine 1 & $\begin{array}{c}\text { Pre-school nursery } \\
\text { Lead Early Years Teacher }\end{array}$ & $\begin{array}{c}41-55 \text { age } \\
\text { range }\end{array}$ & $\begin{array}{c}24 \text { years of } \\
\text { experience in } \\
\text { ECEC }\end{array}$ \\
\hline Zine 2 & $\begin{array}{c}\text { Private Day Nursery } \\
\text { Senior Manager }\end{array}$ & $\begin{array}{c}18-25 \text { age } \\
\text { range }\end{array}$ & $\begin{array}{c}6 \text { years of } \\
\text { experience in } \\
\text { ECEC }\end{array}$ \\
\hline Zine 3 & $\begin{array}{c}\text { Private Day Nursery } \\
\text { Deputy Manager }\end{array}$ & $\begin{array}{c}41-55 \text { age } \\
\text { range }\end{array}$ & $\begin{array}{c}11 \text { years of } \\
\text { experience in } \\
\text { ECEC }\end{array}$ \\
\hline
\end{tabular}

